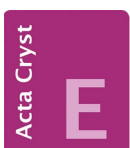

CRYSTALLOGRAPHIC COMMUNICATIONS

ISSN 2056-9890

Received 26 July 2021

Accepted 7 October 2021

‡ These authors contributed equally.

Keywords: crystal structure; chiral; absolute structure; selenium; SBIs; Hirshfeld surface.

CCDC reference: 2114403

Supporting information: this article has supporting information at journals.iucr.org/e

\section{Synthesis and absolute structure of $(R)-2$-(benzyl- selanyl)-1-phenylethanaminium hydrogen sulfate monohydrate: crystal structure and Hirshfeld surface analyses}

\author{
H. R. Rajegowda, ${ }^{a} \ddagger$ P. A. Suchetan, ${ }^{a} \neq$ R. J. Butcher ${ }^{b}$ and P. Raghavendra Kumar ${ }^{a} *$
}

${ }^{\mathbf{a}}$ Department of Chemistry, University College of Science, Tumkur University, Tumkur-572 103, Karnataka, India, and
${ }^{\mathbf{b}}$ Department of Chemistry, Howard University, 525 College Street NW, Washington, DC, 20059, USA. *Correspondence
e-mail: raghukp1@gmail.com

A hydrogen sulfate salt, $\mathrm{C}_{15} \mathrm{H}_{18} \mathrm{NSe}^{+} \cdot \mathrm{HSO}_{4}{ }^{-} \cdot \mathrm{H}_{2} \mathrm{O}$ or $\left[\mathrm{BnSeCH}_{2} \mathrm{CH}(\mathrm{Ph}) \mathrm{NH}_{3}{ }^{+}\right]-$ $\left(\mathrm{HSO}_{4}{ }^{-}\right)$, of a chiral selenated amine $(R)$-2-(benzylselanyl)-1-phenylethanamine $\left(\mathrm{BnSeCH}_{2} \mathrm{CH}(\mathrm{Ph}) \mathrm{NH}_{2}\right)$ has been synthesized and characterized by elemental analysis, ${ }^{1} \mathrm{H}$ and ${ }^{13} \mathrm{C}\left\{{ }^{1} \mathrm{H}\right\}$ NMR, FT-IR analysis, and single-crystal $\mathrm{X}$-ray diffraction studies. The title salt crystallizes in the monohydrate form in the non-centrosymmetric monoclinic $P 2_{1}$ space group. The cation is somewhat $\mathrm{W}$ shaped with the dihedral angle between the two aromatic rings being $60.9(4)^{\circ}$. The carbon atom attached to the amine nitrogen atom is chiral and in the $R$ configuration, and, the $-\mathrm{C}-\mathrm{C}-$ bond of the $-\mathrm{CH}_{2}-\mathrm{CH}-$ fragment has a staggered conformation. In the crystal structure, two $\mathrm{HSO}_{4}{ }^{-}$anions and two water molecules form an $R_{4}^{4}(12)$ tetrameric type of assembly comprised of alternating $\mathrm{HSO}_{4}{ }^{-}$anions and water molecules via discrete $D(2) \mathrm{O}-\mathrm{H} \cdots \mathrm{O}$ hydrogen bonds. This tetrameric assembly aggregates along the $b$-axis direction as an infinite one-dimensional tape. Adjacent tapes are interconnected via discrete $D(2) \mathrm{N}-\mathrm{H} \cdots \mathrm{O}$ hydrogen bonds between the three amino hydrogen atoms of the cation sandwiched between the two tapes and the three $\mathrm{HSO}_{4}{ }^{-}$ anions of the nearest asymmetric units, resulting in a complex two-dimensional sheet along the $a b$ plane. The pendant arrangement of the cations is stabilized by $\mathrm{C}-\mathrm{H} \cdots \pi$ interactions between adjacent cations running as chains down the [010] axis. Secondary Se $\cdots O$ O 3.1474 (4) $\AA$ ] interactions are also observed in the crystal structure. A Hirshfeld surface analysis, including $d_{\text {norm }}$, shape-index and fingerprint plots of the cation, anion and solvent molecule, was carried out to confirm the presence of various interactions in the crystal structure.

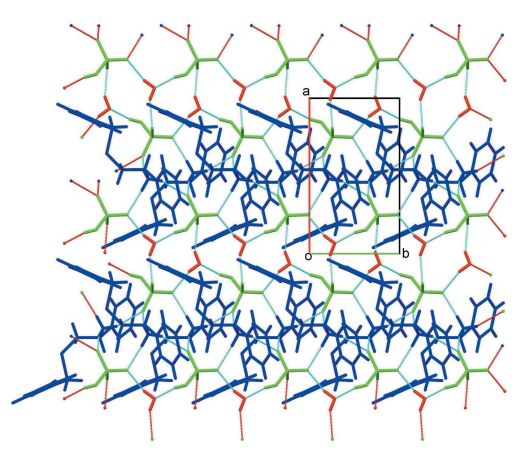

OPEN $\odot$ ACCESS

\section{Chemical context}

Selenium is an important bio-element (Schwarz et al., 1957; Papp et al., 2007). The hypervalent nature of selenium results in interesting secondary bonding interactions (SBIs), also known as non-bonded interactions, in organoselenium compounds (Musher et al., 1969; Raghavendra Kumar et al., 2006; Chivers \& Laitinen, 2015; Bleiholder et al., 2006). These structural aspects are worth exploring as weak SBIs (Iwaoka $e t$ $a l ., 2001,2002 a, b)$ in the compounds of heavy chalcogens (Se and $\mathrm{Te}$ ) are ascribed important roles in structural chemistry, such as the stabilization of otherwise unstable organo-chalcogen compounds and supramolecular associations (Tiekink \& Zukerman-Schpector, 2010; Werz et al., 2002) and possessing biological activities (Reich et al., 2016; Bartolini et al., 2017; Engman et al.,1992; Mukherjee et al., 2010). Some 
organoselenated alkyl/arylamines have been synthesized (Singh \& Srivastava, 1990; Srivastava et al., 1994; Revanna et al., 2015), but further investigations on their single-crystal $\mathrm{X}$-ray structures, especially of chiral derivatives, are limited (Musher et al.,1969; Raghavendra Kumar et al., 2006; Chivers \& Laitinen, 2015; Bleiholder et al., 2006, Prabhu Kumar et al., 2019). Therefore, the synthesis and discussions on the single-crystal structural features of $(R)$-2-(benzylselanyl)-1-phenylethanaminium hydrogen sulfate monohydrate, $\left[\mathrm{BnSeCH}_{2} \mathrm{CH}(\mathrm{Ph}) \mathrm{NH}_{3}{ }^{+}\right]\left(\mathrm{HSO}_{4}{ }^{-}\right)$, are the subject of the present paper.<smiles>N[C@@H](C[Se]c1ccccc1)c1ccccc1</smiles>

\section{Structural commentary}

The title salt (Fig. 1) is formed by the transfer of a proton from sulfuric acid to the chiral selenated amine $\mathrm{C}_{15} \mathrm{H}_{17} \mathrm{SeN}$. The asymmetric unit of the structure consists of one $\left(\mathrm{C}_{15} \mathrm{H}_{18} \mathrm{SeN}\right)^{+}$ cation, one $\mathrm{HSO}_{4}{ }^{-}$anion and a solvent water molecule with no direct hydrogen-bonding interactions between them. In the $\mathrm{HSO}_{4}{ }^{-}$ion, three of the $\mathrm{S}-\mathrm{O}$ bond lengths are almost the same, falling in the range of 1.447 (4)-1.452 (5) $\AA$, while the fourth is slightly elongated at 1.527 (5) $\AA$. This suggests that the three nearly identical $\mathrm{S}-\mathrm{O}$ bonds have partial doublebond character owing to resonance, while the fourth $\mathrm{S}-\mathrm{O}$ bond has single-bond character. This validates the formation of the salt via single proton transfer from sulfuric acid to the amine. The title salt crystallizes in the monohydrate form in the non-centrosymmetric monoclinic $P 2_{1}$ space group. The cation is somewhat W shaped (Fig. 1) with the dihedral angle between the two aromatic rings being $60.9(4)^{\circ}$. The carbon atom attached to the amine nitrogen atom is a chiral atom with an $R$ configuration and the $-\mathrm{C}-\mathrm{C}-$ bond of the $-\mathrm{CH}_{2}-\mathrm{CH}-$ fragment has a staggered conformation.

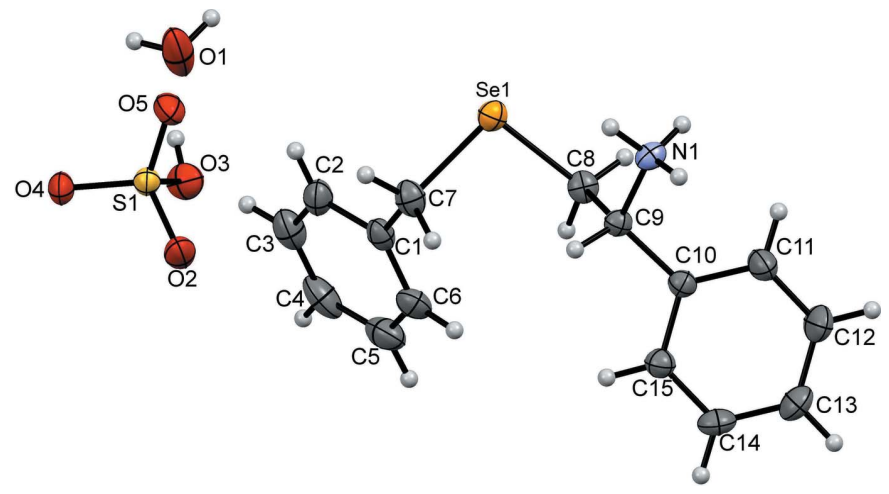

Figure 1

A view of the molecular structure of the title salt, with atom labelling. Displacement ellipsoids are drawn at the $50 \%$ probability level.
Table 1

Hydrogen-bond geometry $\left(\AA,^{\circ}\right)$.

$\mathrm{Cg}$ is the centroid of the $\mathrm{C} 1-\mathrm{C} 6$ aromatic ring.

\begin{tabular}{lllll}
\hline$D-\mathrm{H} \cdots A$ & $D-\mathrm{H}$ & $\mathrm{H} \cdots A$ & $D \cdots A$ & $D-\mathrm{H} \cdots A$ \\
\hline $\mathrm{N} 1-\mathrm{H} 1 A \cdots \mathrm{O} 4^{\mathrm{i}}$ & 0.89 & 2.16 & $3.003(7)$ & 157 \\
$\mathrm{~N} 1-\mathrm{H} 1 B \cdots 4^{\mathrm{ii}}$ & 0.89 & 2.05 & $2.893(6)$ & 159 \\
$\mathrm{~N} 1-\mathrm{H} 1 C \cdots 2^{\mathrm{iii}}$ & 0.89 & 1.92 & $2.812(6)$ & 176 \\
$\mathrm{O} 1-\mathrm{H} 1 D \cdots \mathrm{O} 2^{\mathrm{iv}}$ & 0.85 & 1.91 & $2.726(8)$ & 161 \\
$\mathrm{O} 1-\mathrm{H} 1 E \cdots 5^{\mathrm{v}}$ & 0.85 & 1.95 & $2.730(6)$ & 152 \\
$\mathrm{O} 3-\mathrm{H} 3 A \cdots \mathrm{O} 1$ & 0.82 & 1.68 & $2.483(9)$ & 167 \\
$\mathrm{C} 15-\mathrm{H} 15 \cdots C g^{\mathrm{vi}}$ & 0.93 & 2.75 & $3.547(7)$ & 144 \\
\hline
\end{tabular}

Symmetry codes: (i) $x-1, y+1, z$; (ii) $-x, y+\frac{1}{2},-z$; (iii) $x-1, y, z$; (iv) $x, y-1, z$; (v) $-x, y-\frac{1}{2},-z ;(\mathrm{vi}) x, y+1, z$.

\section{Supramolecular features}

The crystal structure features, by virtue of its salt form, several strong-to-moderate hydrogen bonds, which are not seen to the same extent in the reported freebase structure of the closely related compound (S)-1-(benzylselanyl)-3-phenylpropan-2amine (Prabhu Kumar et al., 2019). The general rule that all strong hydrogen-bond donors participate in hydrogen bonding with strong hydrogen-bond acceptors is totally satisfied in this salt, with all the strong donors and acceptors in the cation, anion and the solvent being involved in at least one hydrogen bond. In the crystal structure, two $\mathrm{HSO}_{4}{ }^{-}$anions and two water molecules are interconnected to form a tetrameric type of assembly comprising of alternating $\mathrm{HSO}_{4}{ }^{-}$ anions and water molecules via discrete $D(2) \mathrm{O} 1-\mathrm{H} 1 D \cdots \mathrm{O} 2$, $\mathrm{O} 1-\mathrm{H} 1 E \cdots \mathrm{O} 5$ and $\mathrm{O} 3-\mathrm{H} 3 A \cdots \mathrm{O} 1$ hydrogen bonds (Fig. 2, Table 1), with the $\mathrm{O} 1-\mathrm{H} 1 E \cdots \mathrm{O} 5$ hydrogen bond appearing twice. This tetrameric type of assembly having a $R_{4}^{4}(12)$ graphset notation aggregates along the $b$-axis direction as an infinite one dimensional tape, with adjacent tetrameric units in the tape glued to each other through the common $\mathrm{O} 1-\mathrm{H} 1 E \ldots \mathrm{O} 5$ hydrogen bonds (Fig. 2). The $\mathrm{O} 1-\mathrm{H} 1 D \cdots \mathrm{O} 2$ and $\mathrm{O} 1-$ $\mathrm{H} 1 E \cdots \mathrm{O} 5$ hydrogen bonds have structure-directing features along the [010] axis. Adjacent tapes, which are 5.2133 (4) $\AA$

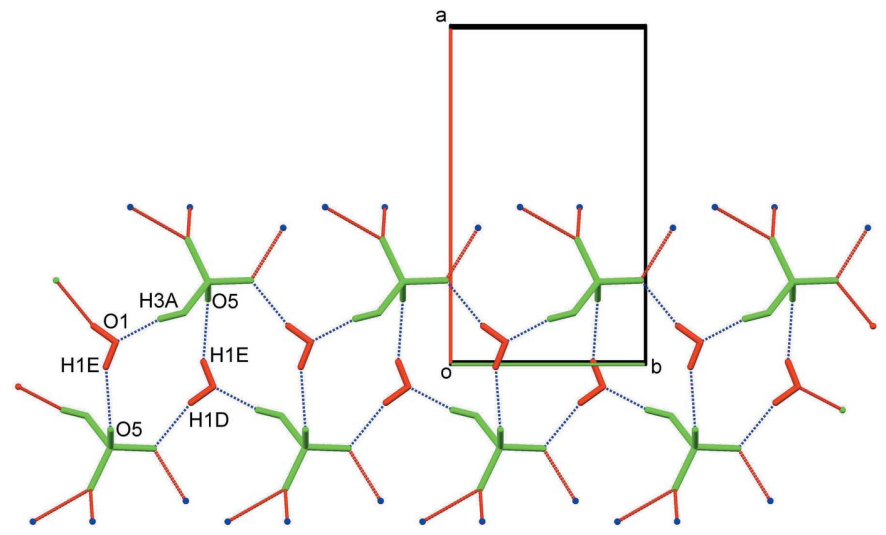

Figure 2

A partial view along the $c$ axis of the crystal packing of the title salt, showing the propagation of the one-dimensional tape along the $b$-axis direction. The various intermolecular interactions (Table 1) are shown as dashed lines. Colour key: green, anions; red, water; blue spheres, cations. 


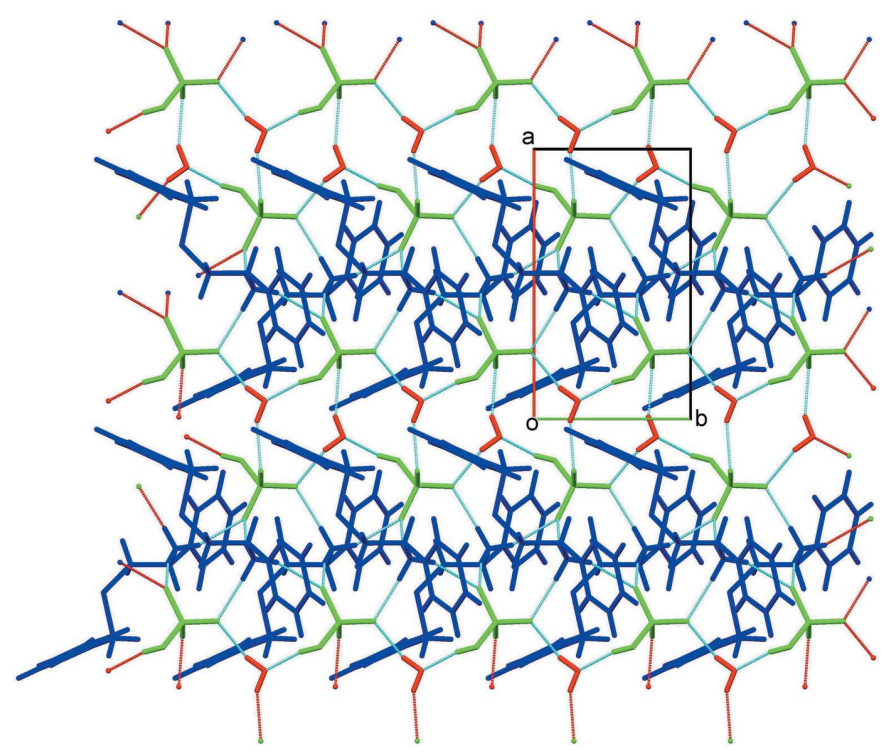

Figure 3

A partial view along the $c$ axis of the crystal packing of the title salt, showing the formation of a two-dimensional sheet along the $a b$ plane. The various intermolecular interactions (Table 1) are shown as dashed lines. Colour key: green, anions; red, water; blue, cations.

apart (i.e. half of the unit-cell length $a$ ) along the $a$ axis, are interconnected via discrete $D(2) \mathrm{N} 1-\mathrm{H} 1 A \cdots \mathrm{O} 4, \mathrm{~N} 1-$ $\mathrm{H} 1 B \cdots \mathrm{O} 4$ and $\mathrm{N} 1-\mathrm{H} 1 C \cdots \mathrm{O} 2$ hydrogen bonds (Fig. 3, Table 1) between the three amino hydrogen atoms of the cation sandwiched between the two tapes and the three $\mathrm{HSO}_{4}{ }^{-}$anions of the nearest asymmetric units (two $\mathrm{HSO}_{4}{ }^{-}$ anions belong to one tape and two to the other), resulting in a complex two-dimensional sheet along the $a b$ plane (Fig. 3). The cations serve as pendants to the complex sheet. The N1$\mathrm{H} 1 A \cdots \mathrm{O} 4, \mathrm{~N} 1-\mathrm{H} 1 B \cdots \mathrm{O} 4$ and $\mathrm{N} 1-\mathrm{H} 1 C \cdots \mathrm{O} 2$ interactions are not structure-directing hydrogen bonds of themselves, but structure-directional characteristics are induced to them via the $\mathrm{O} 1-\mathrm{H} 1 D \cdots \mathrm{O} 2$ and $\mathrm{O} 1-\mathrm{H} 1 E \cdots \mathrm{O} 5$ hydrogen bonds. The pendant-type arrangement of cations is stabilized by $\mathrm{C} 15-$ $\mathrm{H} 15 \cdots \pi$ ( $\pi$ electrons of the C1-C6 ring) interactions between adjacent cations running as chains down the [010] axis. Secondary $\operatorname{Se} 1 \cdots \mathrm{O} 4(x-1, y, z)[3.1474(4) \AA$ interactions are also observed in the crystal structure.

\section{Hirshfeld surface analyses}

The Hirshfeld surfaces including $d_{\text {norm }}$ and shape-index and fingerprint (FP) analyses of the cation, anion and the solvent are shown in Figs. 4 and 5. In the $d_{\text {norm }}$ surface of the cation (highlighting $\mathrm{O} \cdots \mathrm{H} / \mathrm{H} \cdots \mathrm{O}$ contacts only; Fig. 4a), dark-red spots in the proximity of three amino hydrogen atoms are a result of strong $\mathrm{N} 1-\mathrm{H} 1 A \cdots \mathrm{O} 4, \mathrm{~N} 1-\mathrm{H} 1 B \cdots \mathrm{O} 4$ and $\mathrm{N} 1-$ $\mathrm{H} 1 C$. . O 2 hydrogen bonds between the cation and $\mathrm{HSO}_{4}{ }^{-}$ anions. Further, the Hirshfeld surface of the cation mapped over shape-index (highlighting $\mathrm{C} \cdots \mathrm{H} / \mathrm{H} \cdots \mathrm{C}$ contacts only; Fig. $4 b$ ) shows a dark-red spot close to the centroid of the C1C6 ring facing the $\mathrm{H} 15$ hydrogen atom, which is due to the $\mathrm{C} 15-\mathrm{H} 15 \cdots \pi$ ( $\pi$ electrons of the $\mathrm{C} 1-\mathrm{C} 6$ ring) interactions
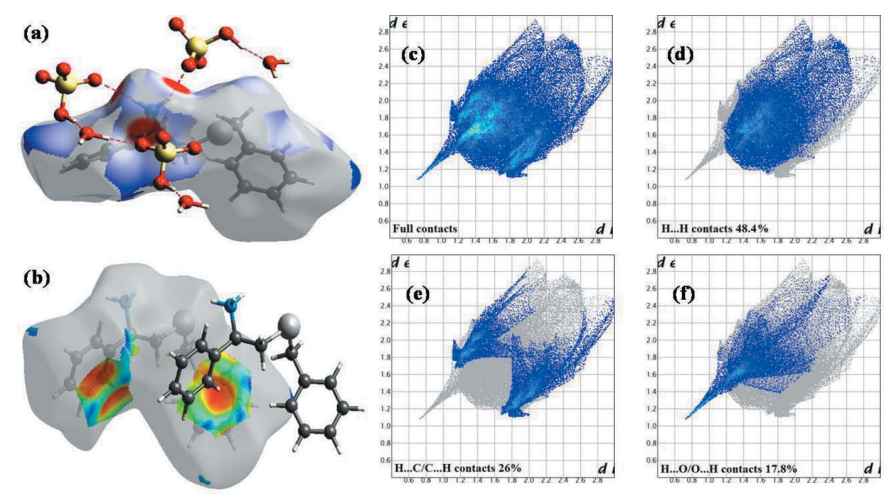

Figure 4

Hirshfeld surfaces comprising $(a) d_{\text {norm }}$ surface, $(b)$ shape-index and $(c)-(f)$ fingerprint plots of the cation.

observed between adjacent cations. The overall FP plot and those decomposed to individual atom ... atom contacts contributing to the Hirshfeld surfaces of the cation are shown in Fig. $4 c, 4 d, 4 e$ and $4 f$, respectively. The highest contribution to the Hirshfeld surface is from $\mathrm{H} \cdots \mathrm{H}$ dispersions, which contribute $48.4 \%$, followed by $\mathrm{C} \cdots \mathrm{H} / \mathrm{H} \cdots \mathrm{C}(26 \%), \mathrm{O} \cdots \mathrm{H} /$ $\mathrm{H} \cdots \mathrm{O}(17.8 \%), \mathrm{Se} \cdots \mathrm{H} / \mathrm{H} \cdots \mathrm{Se}(5.7 \%)$ and others $(2.1 \%)$. The symmetry about the $d_{\mathrm{i}}=d_{\mathrm{e}}$ axis passing through the origin observed in the FP plots for the $\mathrm{H} \cdots \mathrm{H}$ and $\mathrm{C} \cdot \mathrm{H} / \mathrm{H} \cdots \mathrm{C}$ contacts suggests that these interactions exist only between the cationic species and not between cation-anion or cationwater. The asymmetric nature of the FP of the $\mathrm{O} \cdots \mathrm{H} / \mathrm{H} \cdots \mathrm{O}$ contacts about the $d_{\mathrm{i}}=d_{\mathrm{e}}$ axis suggests that the $\mathrm{O} \cdots \mathrm{H}$ interactions are between unlike species, which is in agreement with the observed $\mathrm{N}-\mathrm{H} \cdots \mathrm{O}$ interactions between cations and anions. A single spike observed in the FP of $\mathrm{O} \cdots \mathrm{H} / \mathrm{H} \cdots \mathrm{O}$ contacts is characteristic of a strong or a moderate hydrogen bond. The spike observed at $d_{\mathrm{i}}+d_{\mathrm{e}} \sim 1.9 \AA$ is very close to the $\mathrm{H} 1 C \cdots \mathrm{O} 2$ distance of $1.92 \AA$ (Table 1 ), thus supporting the participation of the cations in various $\mathrm{N}-\mathrm{H} \cdots \mathrm{O}$ hydrogen bonds. Two blunt spikes (a characteristic of a weak interaction between like species) observed in the FP of $\mathrm{C} \cdots \mathrm{H} / \mathrm{H} \cdots \mathrm{C}$ contacts at $d_{\mathrm{i}}+d_{\mathrm{e}} \sim 2.8 \AA$ is very close to the $\mathrm{H} 15 \cdots C g$ distance of $2.75 \AA$ (Table 1 ), thereby confirming the presence
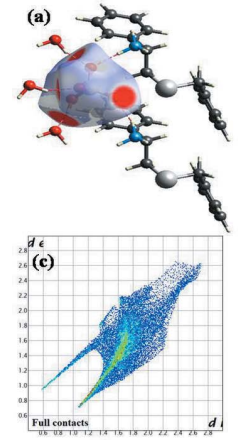

Figure 5

Hirshfeld surfaces: $(a)$ and $(b)$ two different views of the $d_{\text {norm }}$ surface of the anion, $(c)$ and $(d)$ fingerprint plots of the anion, $(e) d_{\text {norm }}$ surface and $(f)$ fingerprint plot of the water molecule.
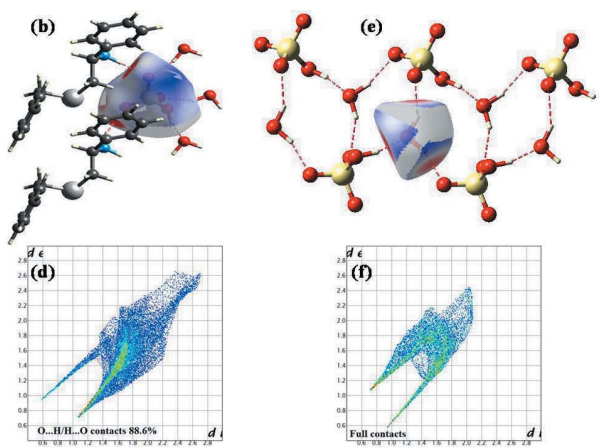
of $\mathrm{C}-\mathrm{H} \cdots \pi$ interactions between the cations. Thus, the Hirshfeld surface analysis provides adequate and reliable evidence, both qualitatively (in terms of pictorial depiction) and quantitatively, for the various interactions in which the cations participate. Analysis of the Hirshfeld surfaces of the anion and the solvent molecule gives similar results (Fig. 5). In the case of the anion, the highest contribution to the Hirshfeld surface is from $\mathrm{O} \cdots \mathrm{H} / \mathrm{H} \cdots \mathrm{O}$ contacts, contributing $88.6 \%$, while for the Hirshfeld surface of water, $61.6 \%$ is from $\mathrm{O} \cdots \mathrm{H} /$ $\mathrm{H} \cdots \mathrm{O}$ contacts and the remaining $38.4 \%$ is from $\mathrm{H} \cdots \mathrm{H}$ dispersions.

\section{Database survey}

The cation of the reported structure is somewhat similar to that observed in a closely related structure, $(S)$-1-(benzylselanyl)-3-phenylpropan-2-amine (Prabhu Kumar et al., 2019), which is homologous to the cation of the title salt with one additional $-\mathrm{CH}_{2}-$ group between the chiral carbon atom and its nearest aromatic ring. The configurations of the chiral carbon atom are different in the two structures. The dihedral angle between the aromatic rings in the related molecule is $66.49(12)^{\circ}$, which is very similar to that observed in the title structure. No intramolecular $\mathrm{N}-\mathrm{H} \cdots \mathrm{Se}$ interaction is observed in the molecular cation of the present structure, unlike in the related molecule where one is observed. In the crystal of the related amine, the molecules are linked by weak $\mathrm{N}-\mathrm{H} \cdots \mathrm{N}$ interactions, generating chains along the [100] direction.

\section{Synthesis and crystallization}

\subsection{Materials and methods}

Chemical reagents were purchased from Sigma-Aldrich (India) and used without further purification unless stated otherwise. For chemical synthesis, reactions were carried out in distilled water or in laboratory-grade solvents at room temperature. Melting points were determined in capillary tubes closed at one end and were reported uncorrected. IR spectra were recorded on a Jasco FT-IR-4100 spectrometer. Specific optical rotations (SOR) were measured on a Rudolph Autopol-I automatic polarimeter using a cell of $100 \mathrm{~mm}$ path length. ${ }^{1} \mathrm{H}$ and ${ }^{13} \mathrm{C}\left\{{ }^{1} \mathrm{H}\right\}$ NMR spectra were recorded on an AVANCE-II Bruker $400 \mathrm{MHz}$ spectrometer. (R)-1-(Benzylselanyl)-2-phenylethan-2-amine was synthesized according to our reported literature procedure (Revanna et al., 2015).

\subsection{Synthesis of (1R)-2-(benzylselanyl)-1-phenylethan-1- ammoniumhydrogensulfate}

The chiral selenated amine (R)-2-(benzylselanyl)-1phenylethanamine was synthesized by a sequence of reactions shown in the reaction scheme starting from $(2 R)$-2-amino-2phenylethan-1-ol [derived from amino acid $(R)$-phenylglycinal] as per the literature procedure (Revanna et al., 2015). The title salt of the above amine was obtained by treating it with sulfuric acid $(5 M)$ in methanol under ice-cold conditions.
Table 2

Experimental details.

\begin{tabular}{|c|c|}
\hline \multicolumn{2}{|l|}{ Crystal data } \\
\hline Chemical formula & $\mathrm{C}_{15} \mathrm{H}_{18} \mathrm{NSe}^{+} \cdot \mathrm{HSO}_{4}{ }^{-} \cdot \mathrm{H}_{2} \mathrm{O}$ \\
\hline$M_{\mathrm{r}}$ & 406.35 \\
\hline Crystal system, space group & Monoclinic, $P 2_{1}$ \\
\hline Temperature $(\mathrm{K})$ & 293 \\
\hline$a, b, c(\AA)$ & $10.4266(4), 6.0539(2), 14.2168(7)$ \\
\hline$\beta\left(^{\circ}\right)$ & $90.261(4)$ \\
\hline$V\left(\AA^{3}\right)$ & $897.38(6)$ \\
\hline$Z$ & 2 \\
\hline Radiation type & Мо $K \alpha$ \\
\hline$\mu\left(\mathrm{mm}^{-1}\right)$ & 2.23 \\
\hline Crystal size $(\mathrm{mm})$ & $0.22 \times 0.18 \times 0.16$ \\
\hline \multicolumn{2}{|l|}{ Data collection } \\
\hline Diffractometer & Bruker APEXII CCD area \\
\hline Absorption correction & $\begin{array}{l}\text { Multi-scan (SADABS; Bruker, } \\
\text { 2009) }\end{array}$ \\
\hline$T_{\min }, T_{\max }$ & $0.624,0.700$ \\
\hline $\begin{array}{l}\text { No. of measured, independent and } \\
\text { observed }[I>2 \sigma(I)] \text { reflections }\end{array}$ & $4255,3088,2624$ \\
\hline$R_{\text {int }}$ & 0.035 \\
\hline$(\sin \theta / \lambda)_{\max }\left(\AA^{-1}\right)$ & 0.649 \\
\hline \multicolumn{2}{|l|}{ Refinement } \\
\hline$R\left[F^{2}>2 \sigma\left(F^{2}\right)\right], w R\left(F^{2}\right), S$ & $0.044,0.113,0.99$ \\
\hline No. of reflections & 3088 \\
\hline No. of parameters & 213 \\
\hline No. of restraints & 1 \\
\hline $\mathrm{H}$-atom treatment & $\mathrm{H}$-atom parameters constrained \\
\hline$\Delta \rho_{\max }, \Delta \rho_{\min }\left(\mathrm{e} \AA^{-3}\right)$ & $0.40,-0.48$ \\
\hline Absolute structure & $\begin{array}{l}\text { Flack } x \text { determined using } 665 \\
\quad \text { quotients }\left[\left(I^{+}\right)-\left(I^{-}\right)\right] /\left[\left(I^{+}\right)+\left(I^{-}\right)\right] \\
\quad \text { (Parsons } \text { et al., 2013) }\end{array}$ \\
\hline Absolute structure parameter & $0.002(16)$ \\
\hline
\end{tabular}

Computer programs: APEX2, SAINT-Plus and XPREP (Bruker, 2009), SHELXT2016/4 (Sheldrick, 2015a), SHELXL2016/4 (Sheldrick, 2015b) and Mercury (Macrae et al., 2020).

To an ice-cold methanolic $(5 \mathrm{~mL})$ solution of $(2 R)$-1-(benzylselanyl)-2-phenylethan-2-amine $(0.291 \mathrm{~g}, 1 \mathrm{mmol})$ was added $5 \mathrm{M}$ of $\mathrm{H}_{2} \mathrm{SO}_{4}(2 \mathrm{~mL})$ under stirring. The resulting precipitate was stirred for a further hour at the same temperature. Then the precipitate was filtered and washed twice with cold methanol $(10 \mathrm{~mL} \times 2)$. The white solid obtained was recrystallized from hot methanol $(10 \mathrm{~mL})$, which afforded colourless crystals of the title salt. The salt is soluble in water, dimethyl formamide (DMF) and dimethyl sulfoxide (DMSO), but insoluble in methanol, chloroform, dichloromethane, ether, tetrahydrofuran (THF) and hydrocarbon solvents such as $n$-hexane, benzene and toluene.

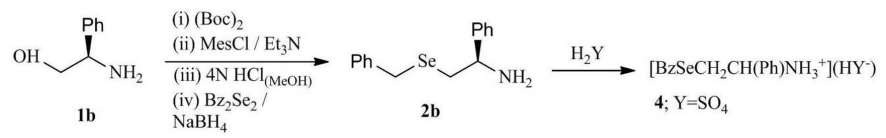

Yield: 92\%; m.p. 469-472 K; ( c 1.0 in MeOH). Elemental analysis: found $\mathrm{C}, 46.51 ; \mathrm{H}, 4.88 ; \mathrm{N}, 3.54$. Calculated for $\mathrm{C}_{15} \mathrm{H}_{19} \mathrm{NO}_{4}$ SSe: C, 46.39; H, 4.93; N, 3.61\%. FT-IR (KBr, v $\mathrm{cm}^{-1}$ ): 3452, 3027, 2925, 1615, 1537, 1361, 1186, 699, 556, 477; ${ }^{1} \mathrm{H}$ NMR (DMSO- $d_{6}, 400.233 \mathrm{MHz}, \delta \mathrm{ppm}$ ): 2.867-3.060 ( $d d$, $\left.2 \mathrm{H}, J=9.2,6.0 \mathrm{~Hz}, \mathrm{CH}_{2} \mathrm{Se}\right), 3.648\left(s, 2 \mathrm{H}, \mathrm{SeCH}_{2}\right), 4.329-4.351$ ( $m, 1 \mathrm{H}, \mathrm{CH}), 7.166-7.288(m, 5 \mathrm{H}, \mathrm{ArH}), 7.373-7.440(m, 5 \mathrm{H}$, ArH), 8.412 (bs, 3H, $\left.\mathrm{NH}_{3}\right) ;{ }^{13} \mathrm{C}\left\{{ }^{1} \mathrm{H}\right\}$ NMR (DMSO- $d_{6}$, $100.638 \mathrm{MHz}, \delta \mathrm{ppm}): 26.99\left(\mathrm{CH}_{2} \mathrm{Se}\right), 27.15\left(\mathrm{SeCH}_{2}\right), 54.75$ 
(CH), 126.89 (C-7), 127.73 (C-13), 128.63 (C-11, C-15), 128.89 (C-6, C-8), 128.99 (C-12, C-14), 129.09 (C-5, C-9), 137.11 (C-4), 139.25 (C-10).

\section{Refinement}

Crystal data, data collection and structure refinement details are summarized in Table 2. The $\mathrm{C}$-bound $\mathrm{H}$ atoms were positioned with idealized geometry and refined using a riding model: $\mathrm{C}-\mathrm{H}=0.93 \AA$ and $U_{\text {iso }}(\mathrm{H})=1.2 U_{\text {eq }}(\mathrm{C})$ for aromatic $\mathrm{H}$ atoms, $\mathrm{C}-\mathrm{H}=0.97 \AA$ and $U_{\text {iso }}(\mathrm{H})=1.2 U_{\text {eq }}(\mathrm{C})$ for methylene $\mathrm{H}$ atoms and $\mathrm{C}-\mathrm{H}=0.98 \AA$ and $U_{\text {iso }}(\mathrm{H})=1.2 U_{\text {eq }}(\mathrm{C})$ for methine $\mathrm{H}$ atoms. The amino $\mathrm{H}$ atoms and $\mathrm{O}$-bound $\mathrm{H}$ atoms were also positioned geometrically and refined as riding: $\mathrm{N}-$ $\mathrm{H}=0.89 \AA$ with $U_{\text {iso }}(\mathrm{H})=1.2 U_{\text {eq }}(\mathrm{N}) ; \mathrm{O}_{\text {water }}-\mathrm{H}=0.85 \AA$ with $U_{\text {iso }}(\mathrm{H})=1.5 U_{\text {eq }}\left(\mathrm{O}_{\text {water }}\right) ; \mathrm{O}_{\text {anion }}-\mathrm{H}=0.82 \AA$ with $U_{\text {iso }}(\mathrm{H})=$ $1.5 U_{\text {eq }}\left(\mathrm{O}_{\text {anion }}\right)$.

\section{Funding information}

PRK thanks the Department of Science and TechnologySERB, New Delhi, India, for financial support in the form of project No. DST/SR/S1/IC-76/2010(G).

\section{References}

Bartolini, D., Sancineto, L., Bem, A. F. D., Tew, K. D., Santi, C., Radi, R., Toquato, P. \& Galli, F. (2017). Selenocompounds in Cancer Therapy: An Overview Advances in Cancer Research. Amsterdam: Elsevier.

Bleiholder, C., Werz, D. B., Köppel, H. \& Gleiter, R. (2006). J. Am. Chem. Soc. 128, 2666-2674.

Bruker (2009). APEX2, SAINT-Plus, XPREP and SADABS. Bruker AXS Inc., Madison, Wisconsin, USA.
Chivers, T. \& Laitinen, R. S. (2015). Chem. Soc. Rev. 44, 1725-1739.

Engman, L., Stern, D., Cotgreave, I. A. \& Andersson, C. M. (1992). J. Am. Chem. Soc. 114, 9737-9743.

Iwaoka, M., Takemoto, S., Okada, M. \& Tomoda, S. (2001). Chem. Lett. 30, 132-133.

Iwaoka, M., Takemoto, S., Okada, M. \& Tomoda, S. (2002a). Bull. Chem. Soc. Jpn, 75, 1611-1625.

Iwaoka, M., Takemoto, S. \& Tomoda, S. (2002b). J. Am. Chem. Soc. 124, 10613-10620.

Macrae, C. F., Sovago, I., Cottrell, S. J., Galek, P. T. A., McCabe, P., Pidcock, E., Platings, M., Shields, G. P., Stevens, J. S., Towler, M. \& Wood, P. A. (2020). J. Appl. Cryst. 53, 226-235.

Mukherjee, A. J., Zade, S. S., Singh, H. B. \& Sunoj, R. B. (2010). Chem. Rev. 110, 4357-4416.

Musher, J. I. (1969). Angew. Chem. Int. Ed. Engl. 8, 54-68.

Papp, L. V., Lu, J., Holmgren, A. \& Khanna, K. K. (2007). Antioxid. \& Redox Signal. 9, 775-806.

Parsons, S., Flack, H. D. \& Wagner, T. (2013). Acta Cryst. B69, 249 259.

Prabhu Kumar, K. M., Palakshamurthy, B. S., Jasinski, J. P., Butcher, R. J. \& Raghavendra Kumar, P. (2019). IUCrData, 4, x191029.

Raghavendra Kumar, P., Upreti, S. \& Singh, A. K. (2006). Inorg. Chim. Acta, 359, 4619-4626.

Reich, H. J. \& Hondal, R. J. (2016). ACS Chem. Biol. 11, 821-841.

Revanna, R. H., Kumar, P. R., Hosamani, A. \& Siddagangaiah, P. B. (2015). J. Organomet. Chem. 799-800, 61-69.

Schwarz, K. \& Foltz, C. M. (1957). J. Am. Chem. Soc. 79, 3292-3293.

Sheldrick, G. M. (2015a). Acta Cryst. A71, 3-8.

Sheldrick, G. M. (2015b). Acta Cryst. C71, 3-8.

Singh, A. K. \& Srivastava, V. (1990). Phosphorus Sulfur Silicon, 47, 471-475.

Srivastava, V., Batheja, R. \& Singh, A. K. (1994). J. Organomet. Chem. 484, 93-96.

Tiekink, E. R. T. \& Zukerman-Schpector, J. (2010). Coord. Chem. Rev. 254, 46-76.

Werz, D. B., Gleiter, R. \& Rominger, F. (2002). J. Am. Chem. Soc. 124, 10638-10639. 


\section{supporting information}

Acta Cryst. (2021). E77, 1062-1066 [https://doi.org/10.1107/S2056989021010409]

Synthesis and absolute structure of $(R)$-2-(benzylselanyl)-1-phenylethanaminium hydrogen sulfate monohydrate: crystal structure and Hirshfeld surface analyses

\section{H. R. Rajegowda, P. A. Suchetan, R. J. Butcher and P. Raghavendra Kumar}

Computing details

Data collection: APEX2 (Bruker, 2009); cell refinement: APEX2 and SAINT-Plus (Bruker, 2009); data reduction: SAINTPlus and XPREP (Bruker, 2009); program(s) used to solve structure: SHELXT2016/4 (Sheldrick, 2015a); program(s) used to refine structure: SHELXL2016/4 (Sheldrick, 2015b); molecular graphics: Mercury (Macrae et al., 2020); software used to prepare material for publication: SHELXL2016/4 (Sheldrick, 2015b).

(R)-2-(Benzylselanyl)-1-phenylethanaminium hydrogen sulfate monohydrate

Crystal data

$\mathrm{C}_{15} \mathrm{H}_{18} \mathrm{NSe}^{+} \cdot \mathrm{HSO}_{4}^{-} \cdot \mathrm{H}_{2} \mathrm{O}$

$M_{r}=406.35$

Monoclinic, $P 2_{1}$

Hall symbol: $\mathrm{P} 2 \mathrm{yb}$

$a=10.4266(4) \AA$

$b=6.0539(2) \AA$

$c=14.2168(7) \AA$

$\beta=90.261(4)^{\circ}$

$V=897.38(6) \AA^{3}$

$Z=2$

\section{Data collection}

Bruker APEXII CCD area diffractometer

Radiation source: sealed X-ray tube Graphite monochromator phi and $\varphi$ scans

Absorption correction: multi-scan (SADABS; Bruker, 2009)

$T_{\min }=0.624, T_{\max }=0.700$

\section{Refinement}

Refinement on $F^{2}$

Least-squares matrix: full

$R\left[F^{2}>2 \sigma\left(F^{2}\right)\right]=0.044$

$w R\left(F^{2}\right)=0.113$

$S=0.99$

3088 reflections

213 parameters
$F(000)=416$

Prism

$D_{\mathrm{x}}=1.504 \mathrm{Mg} \mathrm{m}^{-3}$

Mo $K \alpha$ radiation, $\lambda=0.71073 \AA$

Cell parameters from 1021 reflections

$\theta=2.4-27.5^{\circ}$

$\mu=2.23 \mathrm{~mm}^{-1}$

$T=293 \mathrm{~K}$

Prism, colourless

$0.22 \times 0.18 \times 0.16 \mathrm{~mm}$

4255 measured reflections

3088 independent reflections

2624 reflections with $I>2 \sigma(I)$

$R_{\text {int }}=0.035$

$\theta_{\text {max }}=27.5^{\circ}, \theta_{\min }=2.4^{\circ}$

$h=-12 \rightarrow 13$

$k=-6 \rightarrow 7$

$l=-16 \rightarrow 18$

1 restraint

Hydrogen site location: mixed

$\mathrm{H}$-atom parameters constrained

$w=1 /\left[\sigma^{2}\left(F_{0}^{2}\right)+(0.0556 P)^{2}\right]$

where $P=\left(F_{\mathrm{o}}^{2}+2 F_{\mathrm{c}}{ }^{2}\right) / 3$

$(\Delta / \sigma)_{\max }<0.001$

$\Delta \rho_{\max }=0.40 \mathrm{e} \AA^{-3}$ 
$\Delta \rho_{\min }=-0.48$ e $\AA^{-3}$
Absolute structure: Flack $x$ determined using 665 quotients $\left[\left(I^{+}\right)-\left(I^{-}\right)\right] /\left[\left(I^{+}\right)+\left(I^{-}\right)\right]$(Parsons et al., 2013)

Absolute structure parameter: $0.002(16)$

Special details

Geometry. All esds (except the esd in the dihedral angle between two 1.s. planes) are estimated using the full covariance matrix. The cell esds are taken into account individually in the estimation of esds in distances, angles and torsion angles; correlations between esds in cell parameters are only used when they are defined by crystal symmetry. An approximate (isotropic) treatment of cell esds is used for estimating esds involving l.s. planes.

Fractional atomic coordinates and isotropic or equivalent isotropic displacement parameters $\left(\AA^{2}\right)$

\begin{tabular}{|c|c|c|c|c|}
\hline & $x$ & $y$ & $z$ & $U_{\text {iso }} * / U_{\text {eq }}$ \\
\hline $\mathrm{O} 2$ & $0.2505(4)$ & $-0.0248(8)$ & $-0.0946(4)$ & $0.0611(14)$ \\
\hline $\mathrm{C} 3$ & $-0.0762(7)$ & $-0.6548(14)$ & $-0.3497(6)$ & $0.067(2)$ \\
\hline H3 & -0.038625 & -0.793146 & -0.342466 & $0.080^{*}$ \\
\hline $\mathrm{C} 2$ & $-0.1040(6)$ & $-0.5295(12)$ & $-0.2720(6)$ & $0.0556(19)$ \\
\hline $\mathrm{H} 2$ & -0.086191 & -0.584727 & -0.212284 & $0.067^{*}$ \\
\hline N1 & $-0.5188(4)$ & $0.2116(9)$ & $-0.1128(3)$ & $0.0392(13)$ \\
\hline H1A & -0.531807 & 0.355694 & -0.104787 & $0.047^{*}$ \\
\hline H1B & -0.466298 & 0.161851 & -0.068113 & $0.047^{*}$ \\
\hline $\mathrm{H} 1 \mathrm{C}$ & -0.593408 & 0.140600 & -0.109508 & $0.047^{*}$ \\
\hline $\mathrm{O} 4$ & $0.3706(4)$ & $-0.3492(8)$ & $-0.0578(3)$ & $0.0476(11)$ \\
\hline $\mathrm{O} 3$ & $0.1539(5)$ & $-0.3689(10)$ & $-0.1198(4)$ & $0.0627(14)$ \\
\hline $\mathrm{H} 3 \mathrm{~A}$ & 0.136250 & -0.489162 & -0.096649 & $0.094 *$ \\
\hline $\mathrm{O} 1$ & $0.0666(5)$ & $-0.7188(11)$ & $-0.0553(7)$ & $0.097(2)$ \\
\hline H1D & 0.114172 & -0.832572 & -0.058680 & $0.145^{*}$ \\
\hline H1E & -0.007149 & -0.769210 & -0.041900 & $0.145^{*}$ \\
\hline SE1 & $-0.35634(5)$ & $-0.25057(7)$ & $-0.14135(4)$ & $0.04370(19)$ \\
\hline S1 & $0.24573(11)$ & $-0.2451(4)$ & -0.05445 (9) & $0.0386(3)$ \\
\hline $\mathrm{O} 5$ & $0.1938(3)$ & $-0.2455(14)$ & $0.0397(3)$ & $0.0577(11)$ \\
\hline C6 & $-0.1847(6)$ & $-0.239(2)$ & $-0.3707(5)$ & $0.0576(17)$ \\
\hline H6 & -0.218500 & -0.097722 & -0.378626 & $0.069^{*}$ \\
\hline $\mathrm{C} 10$ & $-0.5289(5)$ & $0.3042(9)$ & $-0.2820(4)$ & $0.0377(16)$ \\
\hline $\mathrm{C} 15$ & $-0.4578(6)$ & $0.3885(12)$ & $-0.3559(5)$ & $0.0449(15)$ \\
\hline H15 & -0.370318 & 0.359532 & -0.359223 & $0.054^{*}$ \\
\hline $\mathrm{C} 4$ & $-0.1034(7)$ & $-0.5772(18)$ & $-0.4374(7)$ & $0.077(3)$ \\
\hline $\mathrm{H} 4$ & -0.084348 & -0.662521 & -0.489933 & $0.092 *$ \\
\hline $\mathrm{C} 1$ & $-0.1588(5)$ & $-0.3192(11)$ & $-0.2815(5)$ & $0.0463(16)$ \\
\hline $\mathrm{C} 9$ & $-0.4594(5)$ & $0.1722(10)$ & $-0.2082(4)$ & $0.0360(13)$ \\
\hline H9 & -0.370076 & 0.222507 & -0.205826 & $0.043^{*}$ \\
\hline $\mathrm{C} 12$ & $-0.7151(7)$ & $0.4805(15)$ & $-0.3469(6)$ & $0.068(2)$ \\
\hline $\mathrm{H} 12$ & -0.802097 & 0.513070 & -0.342967 & $0.081^{*}$ \\
\hline $\mathrm{C} 14$ & $-0.5161(7)$ & $0.5156(13)$ & $-0.4248(5)$ & $0.0546(18)$ \\
\hline H14 & -0.467590 & 0.568783 & -0.474659 & $0.066^{*}$ \\
\hline $\mathrm{C} 8$ & $-0.4598(6)$ & $-0.0755(10)$ & $-0.2284(5)$ & $0.0404(14)$ \\
\hline $\mathrm{H} 8 \mathrm{~A}$ & -0.428439 & -0.099360 & -0.291714 & $0.048^{*}$ \\
\hline H8B & -0.547581 & -0.128372 & -0.226248 & $0.048^{*}$ \\
\hline
\end{tabular}




$\begin{array}{lllll}\text { C11 } & -0.6591(6) & 0.3503(14) & -0.2794(5) & 0.0573(19) \\ \text { H11 } & -0.708984 & 0.292124 & -0.231368 & 0.069^{*} \\ \text { C13 } & -0.6443(7) & 0.5641(14) & -0.4206(5) & 0.061(2) \\ \text { H13 } & -0.682844 & 0.651632 & -0.466410 & 0.073^{*} \\ \text { C7 } & -0.1873(6) & -0.1864(11) & -0.1955(5) & 0.0531(19) \\ \text { H7A } & -0.183063 & -0.030709 & -0.211244 & 0.064^{*} \\ \text { H7B } & -0.121754 & -0.215704 & -0.148436 & 0.064^{*} \\ \text { C5 } & -0.1593(8) & -0.3717(18) & -0.4485(6) & 0.075(3) \\ \text { H5 } & -0.180219 & -0.321648 & -0.508514 & 0.090^{*}\end{array}$

Atomic displacement parameters $\left(\AA^{2}\right)$

\begin{tabular}{lllllll}
\hline & $U^{11}$ & $U^{22}$ & $U^{33}$ & $U^{12}$ & $U^{13}$ & $U^{23}$ \\
\hline O2 & $0.050(3)$ & $0.044(3)$ & $0.089(4)$ & $0.003(2)$ & $0.009(3)$ & $0.018(3)$ \\
C3 & $0.048(4)$ & $0.058(5)$ & $0.094(7)$ & $0.000(4)$ & $0.012(4)$ & $-0.013(5)$ \\
C2 & $0.044(4)$ & $0.048(4)$ & $0.074(5)$ & $0.005(3)$ & $-0.001(3)$ & $0.001(4)$ \\
N1 & $0.050(2)$ & $0.034(4)$ & $0.033(2)$ & $0.002(2)$ & $-0.0048(19)$ & $-0.002(2)$ \\
O4 & $0.038(2)$ & $0.052(3)$ & $0.053(3)$ & $0.012(2)$ & $0.0011(19)$ & $0.001(2)$ \\
O3 & $0.057(3)$ & $0.068(3)$ & $0.064(3)$ & $-0.017(3)$ & $-0.014(3)$ & $0.002(3)$ \\
O1 & $0.050(3)$ & $0.044(4)$ & $0.197(7)$ & $0.001(3)$ & $0.022(4)$ & $0.008(4)$ \\
SE1 & $0.0484(3)$ & $0.0345(3)$ & $0.0482(3)$ & $0.0023(4)$ & $0.0009(2)$ & $-0.0026(4)$ \\
S1 & $0.0342(6)$ & $0.0356(6)$ & $0.0460(7)$ & $0.0004(10)$ & $0.0002(5)$ & $0.0031(11)$ \\
O5 & $0.048(2)$ & $0.077(3)$ & $0.049(2)$ & $0.010(3)$ & $0.0103(18)$ & $0.004(4)$ \\
C6 & $0.050(3)$ & $0.060(4)$ & $0.064(4)$ & $-0.014(5)$ & $0.011(3)$ & $0.006(6)$ \\
C10 & $0.038(3)$ & $0.037(4)$ & $0.038(3)$ & $-0.002(2)$ & $0.001(2)$ & $-0.001(2)$ \\
C15 & $0.045(3)$ & $0.048(4)$ & $0.041(4)$ & $-0.002(3)$ & $0.002(3)$ & $0.002(3)$ \\
C4 & $0.056(5)$ & $0.089(7)$ & $0.084(7)$ & $-0.011(5)$ & $0.028(5)$ & $-0.032(6)$ \\
C1 & $0.034(3)$ & $0.042(4)$ & $0.062(4)$ & $-0.005(3)$ & $0.007(3)$ & $-0.002(3)$ \\
C9 & $0.039(3)$ & $0.032(3)$ & $0.037(3)$ & $-0.001(2)$ & $0.002(2)$ & $-0.001(2)$ \\
C12 & $0.044(4)$ & $0.093(7)$ & $0.065(5)$ & $0.006(4)$ & $-0.014(4)$ & $0.015(5)$ \\
C14 & $0.072(5)$ & $0.055(4)$ & $0.037(4)$ & $-0.005(4)$ & $0.004(3)$ & $0.009(3)$ \\
C8 & $0.044(3)$ & $0.036(3)$ & $0.041(3)$ & $-0.003(3)$ & $-0.003(3)$ & $-0.012(3)$ \\
C11 & $0.039(3)$ & $0.079(5)$ & $0.054(4)$ & $0.000(3)$ & $0.003(3)$ & $0.009(4)$ \\
C13 & $0.065(5)$ & $0.065(5)$ & $0.053(5)$ & $0.008(4)$ & $-0.017(4)$ & $0.010(4)$ \\
C7 & $0.043(3)$ & $0.051(5)$ & $0.065(4)$ & $-0.004(3)$ & $0.000(3)$ & $-0.011(3)$ \\
C5 & $0.060(5)$ & $0.103(7)$ & $0.063(5)$ & $-0.019(5)$ & $0.012(4)$ & $0.008(5)$ \\
& & & & & & \\
\hline
\end{tabular}

Geometric parameters $\left(\stackrel{A}{\circ}{ }^{\circ}\right)$

\begin{tabular}{llll}
\hline $\mathrm{O} 2-\mathrm{S} 1$ & $1.452(5)$ & $\mathrm{C} 10-\mathrm{C} 11$ & $1.386(8)$ \\
$\mathrm{C} 3-\mathrm{C} 4$ & $1.361(13)$ & $\mathrm{C} 10-\mathrm{C} 9$ & $1.503(8)$ \\
$\mathrm{C} 3-\mathrm{C} 2$ & $1.373(10)$ & $\mathrm{C} 15-\mathrm{C} 14$ & $1.384(9)$ \\
$\mathrm{C} 3-\mathrm{H} 3$ & 0.9300 & $\mathrm{C} 15-\mathrm{H} 15$ & 0.9300 \\
$\mathrm{C} 2-\mathrm{C} 1$ & $1.402(10)$ & $\mathrm{C} 4-\mathrm{C} 5$ & $1.383(14)$ \\
$\mathrm{C} 2-\mathrm{H} 2$ & 0.9300 & $\mathrm{C} 4-\mathrm{H} 4$ & 0.9300 \\
$\mathrm{~N} 1-\mathrm{C} 9$ & $1.512(7)$ & $\mathrm{C} 1-\mathrm{C} 7$ & $1.495(9)$ \\
$\mathrm{N} 1-\mathrm{H} 1 \mathrm{~A}$ & 0.8900 & $\mathrm{C} 9-\mathrm{C} 8$ & $1.527(8)$ \\
$\mathrm{N} 1-\mathrm{H} 1 \mathrm{~B}$ & 0.8900 & $\mathrm{C} 9-\mathrm{H} 9$ & 0.9800
\end{tabular}




\begin{tabular}{|c|c|c|c|}
\hline $\mathrm{N} 1-\mathrm{H} 1 \mathrm{C}$ & 0.8900 & $\mathrm{C} 12-\mathrm{C} 11$ & $1.370(10)$ \\
\hline $\mathrm{O} 4-\mathrm{S} 1$ & $1.447(4)$ & $\mathrm{C} 12-\mathrm{C} 13$ & $1.380(11)$ \\
\hline $\mathrm{O} 3-\mathrm{S} 1$ & $1.527(5)$ & $\mathrm{C} 12-\mathrm{H} 12$ & 0.9300 \\
\hline $\mathrm{O} 3-\mathrm{H} 3 \mathrm{~A}$ & 0.8200 & $\mathrm{C} 14-\mathrm{C} 13$ & $1.370(10)$ \\
\hline $\mathrm{O} 1-\mathrm{H} 1 \mathrm{D}$ & 0.8500 & $\mathrm{C} 14-\mathrm{H} 14$ & 0.9300 \\
\hline $\mathrm{O} 1-\mathrm{H} 1 \mathrm{E}$ & 0.8500 & $\mathrm{C} 8-\mathrm{H} 8 \mathrm{~A}$ & 0.9700 \\
\hline $\mathrm{Se} 1-\mathrm{C} 8$ & $1.951(6)$ & $\mathrm{C} 8-\mathrm{H} 8 \mathrm{~B}$ & 0.9700 \\
\hline $\mathrm{Se} 1-\mathrm{C} 7$ & $1.965(6)$ & $\mathrm{C} 11-\mathrm{H} 11$ & 0.9300 \\
\hline $\mathrm{S} 1-\mathrm{O} 5$ & $1.447(4)$ & $\mathrm{C} 13-\mathrm{H} 13$ & 0.9300 \\
\hline $\mathrm{C} 6-\mathrm{C} 1$ & $1.384(10)$ & $\mathrm{C} 7-\mathrm{H} 7 \mathrm{~A}$ & 0.9700 \\
\hline $\mathrm{C} 6-\mathrm{C} 5$ & $1.395(13)$ & $\mathrm{C} 7-\mathrm{H} 7 \mathrm{~B}$ & 0.9700 \\
\hline $\mathrm{C} 6-\mathrm{H} 6$ & 0.9300 & $\mathrm{C} 5-\mathrm{H} 5$ & 0.9300 \\
\hline $\mathrm{C} 10-\mathrm{C} 15$ & $1.387(8)$ & & \\
\hline $\mathrm{C} 4-\mathrm{C} 3-\mathrm{C} 2$ & $120.2(8)$ & $\mathrm{C} 2-\mathrm{C} 1-\mathrm{C} 7$ & $119.5(7)$ \\
\hline $\mathrm{C} 4-\mathrm{C} 3-\mathrm{H} 3$ & 119.9 & $\mathrm{C} 10-\mathrm{C} 9-\mathrm{N} 1$ & $110.1(4)$ \\
\hline $\mathrm{C} 2-\mathrm{C} 3-\mathrm{H} 3$ & 119.9 & $\mathrm{C} 10-\mathrm{C} 9-\mathrm{C} 8$ & $112.9(5)$ \\
\hline $\mathrm{C} 3-\mathrm{C} 2-\mathrm{C} 1$ & $120.8(8)$ & $\mathrm{N} 1-\mathrm{C} 9-\mathrm{C} 8$ & $108.8(5)$ \\
\hline $\mathrm{C} 3-\mathrm{C} 2-\mathrm{H} 2$ & 119.6 & $\mathrm{C} 10-\mathrm{C} 9-\mathrm{H} 9$ & 108.3 \\
\hline $\mathrm{C} 1-\mathrm{C} 2-\mathrm{H} 2$ & 119.6 & $\mathrm{~N} 1-\mathrm{C} 9-\mathrm{H} 9$ & 108.3 \\
\hline $\mathrm{C} 9-\mathrm{N} 1-\mathrm{H} 1 \mathrm{~A}$ & 109.5 & $\mathrm{C} 8-\mathrm{C} 9-\mathrm{H} 9$ & 108.3 \\
\hline $\mathrm{C} 9-\mathrm{N} 1-\mathrm{H} 1 \mathrm{~B}$ & 109.5 & $\mathrm{C} 11-\mathrm{C} 12-\mathrm{C} 13$ & $120.9(7)$ \\
\hline $\mathrm{H} 1 \mathrm{~A}-\mathrm{N} 1-\mathrm{H} 1 \mathrm{~B}$ & 109.5 & $\mathrm{C} 11-\mathrm{C} 12-\mathrm{H} 12$ & 119.5 \\
\hline $\mathrm{C} 9-\mathrm{N} 1-\mathrm{H} 1 \mathrm{C}$ & 109.5 & $\mathrm{C} 13-\mathrm{C} 12-\mathrm{H} 12$ & 119.5 \\
\hline $\mathrm{H} 1 \mathrm{~A}-\mathrm{N} 1-\mathrm{H} 1 \mathrm{C}$ & 109.5 & $\mathrm{C} 13-\mathrm{C} 14-\mathrm{C} 15$ & $120.9(7)$ \\
\hline $\mathrm{H} 1 \mathrm{~B}-\mathrm{N} 1-\mathrm{H} 1 \mathrm{C}$ & 109.5 & $\mathrm{C} 13-\mathrm{C} 14-\mathrm{H} 14$ & 119.6 \\
\hline $\mathrm{S} 1-\mathrm{O} 3-\mathrm{H} 3 \mathrm{~A}$ & 109.5 & $\mathrm{C} 15-\mathrm{C} 14-\mathrm{H} 14$ & 119.6 \\
\hline $\mathrm{H} 1 \mathrm{D}-\mathrm{O} 1-\mathrm{H} 1 \mathrm{E}$ & 104.5 & $\mathrm{C} 9-\mathrm{C} 8-\mathrm{Se} 1$ & $114.4(4)$ \\
\hline $\mathrm{C} 8-\mathrm{Se} 1-\mathrm{C} 7$ & $98.0(3)$ & $\mathrm{C} 9-\mathrm{C} 8-\mathrm{H} 8 \mathrm{~A}$ & 108.7 \\
\hline $\mathrm{O} 5-\mathrm{S} 1-\mathrm{O} 4$ & $111.7(3)$ & $\mathrm{Se} 1-\mathrm{C} 8-\mathrm{H} 8 \mathrm{~A}$ & 108.7 \\
\hline $\mathrm{O} 5-\mathrm{S} 1-\mathrm{O} 2$ & $112.3(4)$ & C9- $88-\mathrm{H} 8 \mathrm{~B}$ & 108.7 \\
\hline $\mathrm{O} 4-\mathrm{S} 1-\mathrm{O} 2$ & $110.8(3)$ & $\mathrm{Se} 1-\mathrm{C} 8-\mathrm{H} 8 \mathrm{~B}$ & 108.7 \\
\hline $\mathrm{O} 5-\mathrm{S} 1-\mathrm{O} 3$ & $109.0(3)$ & $\mathrm{H} 8 \mathrm{~A}-\mathrm{C} 8-\mathrm{H} 8 \mathrm{~B}$ & 107.6 \\
\hline $\mathrm{O} 4-\mathrm{S} 1-\mathrm{O} 3$ & $109.1(3)$ & $\mathrm{C} 12-\mathrm{C} 11-\mathrm{C} 10$ & $120.8(6)$ \\
\hline $\mathrm{O} 2-\mathrm{S} 1-\mathrm{O} 3$ & $103.6(3)$ & $\mathrm{C} 12-\mathrm{C} 11-\mathrm{H} 11$ & 119.6 \\
\hline $\mathrm{C} 1-\mathrm{C} 6-\mathrm{C} 5$ & $119.1(10)$ & $\mathrm{C} 10-\mathrm{C} 11-\mathrm{H} 11$ & 119.6 \\
\hline $\mathrm{C} 1-\mathrm{C} 6-\mathrm{H} 6$ & 120.4 & $\mathrm{C} 14-\mathrm{C} 13-\mathrm{C} 12$ & $118.7(7)$ \\
\hline $\mathrm{C} 5-\mathrm{C} 6-\mathrm{H} 6$ & 120.4 & $\mathrm{C} 14-\mathrm{C} 13-\mathrm{H} 13$ & 120.6 \\
\hline $\mathrm{C} 15-\mathrm{C} 10-\mathrm{C} 11$ & $118.2(6)$ & $\mathrm{C} 12-\mathrm{C} 13-\mathrm{H} 13$ & 120.6 \\
\hline $\mathrm{C} 15-\mathrm{C} 10-\mathrm{C} 9$ & $117.8(5)$ & $\mathrm{C} 1-\mathrm{C} 7-\mathrm{Se} 1$ & $113.3(4)$ \\
\hline $\mathrm{C} 11-\mathrm{C} 10-\mathrm{C} 9$ & $123.9(5)$ & $\mathrm{C} 1-\mathrm{C} 7-\mathrm{H} 7 \mathrm{~A}$ & 108.9 \\
\hline $\mathrm{C} 10-\mathrm{C} 15-\mathrm{C} 14$ & $120.4(6)$ & $\mathrm{Se} 1-\mathrm{C} 7-\mathrm{H} 7 \mathrm{~A}$ & 108.9 \\
\hline $\mathrm{C} 10-\mathrm{C} 15-\mathrm{H} 15$ & 119.8 & $\mathrm{C} 1-\mathrm{C} 7-\mathrm{H} 7 \mathrm{~B}$ & 108.9 \\
\hline $\mathrm{C} 14-\mathrm{C} 15-\mathrm{H} 15$ & 119.8 & $\mathrm{Se} 1-\mathrm{C} 7-\mathrm{H} 7 \mathrm{~B}$ & 108.9 \\
\hline $\mathrm{C} 3-\mathrm{C} 4-\mathrm{C} 5$ & $120.1(9)$ & $\mathrm{H} 7 \mathrm{~A}-\mathrm{C} 7-\mathrm{H} 7 \mathrm{~B}$ & 107.7 \\
\hline $\mathrm{C} 3-\mathrm{C} 4-\mathrm{H} 4$ & 120.0 & $\mathrm{C} 4-\mathrm{C} 5-\mathrm{C} 6$ & $120.7(9)$ \\
\hline $\mathrm{C} 5-\mathrm{C} 4-\mathrm{H} 4$ & 120.0 & $\mathrm{C} 4-\mathrm{C} 5-\mathrm{H} 5$ & 119.7 \\
\hline $\mathrm{C} 6-\mathrm{C} 1-\mathrm{C} 2$ & $119.1(8)$ & $\mathrm{C} 6-\mathrm{C} 5-\mathrm{H} 5$ & 119.7 \\
\hline
\end{tabular}




$\begin{array}{llll}\mathrm{C} 6-\mathrm{C} 1-\mathrm{C} 7 & 121.5(7) & & \\ \mathrm{C} 4-\mathrm{C} 3-\mathrm{C} 2-\mathrm{C} 1 & -0.9(12) & \mathrm{C} 10-\mathrm{C} 15-\mathrm{C} 14-\mathrm{C} 13 & 1.2(11) \\ \mathrm{C} 11-\mathrm{C} 10-\mathrm{C} 15-\mathrm{C} 14 & 0.1(10) & \mathrm{C} 10-\mathrm{C} 9-\mathrm{C} 8-\mathrm{Se} 1 & 174.2(4) \\ \mathrm{C} 9-\mathrm{C} 10-\mathrm{C} 15-\mathrm{C} 14 & -178.5(6) & \mathrm{N} 1-\mathrm{C} 9-\mathrm{C} 8-\mathrm{Se} 1 & -63.2(5) \\ \mathrm{C} 2-\mathrm{C} 3-\mathrm{C} 4-\mathrm{C} 5 & -0.1(13) & \mathrm{C} 13-\mathrm{C} 12-\mathrm{C} 11-\mathrm{C} 10 & 1.8(13) \\ \mathrm{C} 5-\mathrm{C} 6-\mathrm{C} 1-\mathrm{C} 2 & 2.0(10) & \mathrm{C} 15-\mathrm{C} 10-\mathrm{C} 11-\mathrm{C} 12 & -1.7(11) \\ \mathrm{C} 5-\mathrm{C} 6-\mathrm{C} 1-\mathrm{C} 7 & -178.4(6) & \mathrm{C} 9-\mathrm{C} 10-\mathrm{C} 11-\mathrm{C} 12 & 176.9(7) \\ \mathrm{C} 3-\mathrm{C} 2-\mathrm{C} 1-\mathrm{C} 6 & -0.1(10) & \mathrm{C} 15-\mathrm{C} 14-\mathrm{C} 13-\mathrm{C} 12 & -1.1(12) \\ \mathrm{C} 3-\mathrm{C} 2-\mathrm{C} 1-\mathrm{C} 7 & -179.7(6) & \mathrm{C} 11-\mathrm{C} 12-\mathrm{C} 13-\mathrm{C} 14 & -0.4(13) \\ \mathrm{C} 15-\mathrm{C} 10-\mathrm{C} 9-\mathrm{N} 1 & 145.4(5) & \mathrm{C} 6-\mathrm{C} 1-\mathrm{C} 7-\mathrm{Se} 1 & 93.7(6) \\ \mathrm{C} 11-\mathrm{C} 10-\mathrm{C} 9-\mathrm{N} 1 & -33.1(8) & \mathrm{C} 2-\mathrm{C} 1-\mathrm{C} 7-\mathrm{Se} 1 & -86.7(7) \\ \mathrm{C} 15-\mathrm{C} 10-\mathrm{C} 9-\mathrm{C} 8 & -92.7(6) & \mathrm{C} 3-\mathrm{C} 4-\mathrm{C} 5-\mathrm{C} 6 & 2.1(13) \\ \mathrm{C} 11-\mathrm{C} 10-\mathrm{C} 9-\mathrm{C} 8 & 88.7(7) & \mathrm{C} 1-\mathrm{C} 6-\mathrm{C} 5-\mathrm{C} 4 & -3.1(11) \\ & & & \end{array}$

Hydrogen-bond geometry $\left(\AA,{ }^{\circ}\right)$

$\mathrm{Cg}$ is the centroid of the $\mathrm{C} 1-\mathrm{C} 6$ aromatic ring.

\begin{tabular}{lllll}
\hline$D-\mathrm{H} \cdots A$ & $D-\mathrm{H}$ & $\mathrm{H} \cdots A$ & $D \cdots A$ & $D-\mathrm{H} \cdots A$ \\
\hline $\mathrm{N} 1-\mathrm{H} 1 A \cdots \mathrm{O} 4^{\mathrm{i}}$ & 0.89 & 2.16 & $3.003(7)$ & 157 \\
$\mathrm{~N} 1-\mathrm{H} 1 B \cdots{ }^{4 i}$ & 0.89 & 2.05 & $2.893(6)$ & 159 \\
$\mathrm{~N} 1-\mathrm{H} 1 C \cdots \mathrm{O} 2^{\mathrm{iii}}$ & 0.89 & 1.92 & $2.812(6)$ & 176 \\
$\mathrm{O} 1-\mathrm{H} 1 D \cdots \mathrm{O} 2^{\mathrm{iv}}$ & 0.85 & 1.91 & $2.726(8)$ & 161 \\
$\mathrm{O} 1-\mathrm{H} 1 E^{\cdots} \cdots 5^{\mathrm{v}}$ & 0.85 & 1.95 & $2.730(6)$ & 152 \\
$\mathrm{O} 3-\mathrm{H} 3 A \cdots \mathrm{O} 1$ & 0.82 & 1.68 & $2.483(9)$ & 167 \\
$\mathrm{C} 15-\mathrm{H} 15 \cdots C g^{\mathrm{vi}}$ & 0.93 & 2.75 & $3.547(7)$ & 144 \\
\hline
\end{tabular}

Symmetry codes: (i) $x-1, y+1, z$; (ii) $-x, y+1 / 2,-z$; (iii) $x-1, y, z$; (iv) $x, y-1, z$; (v) $-x, y-1 / 2,-z$; (vi) $x, y+1, z$. 